\title{
The Level of Obesity and the Incidence Varicose Vein on Adult Patients in Public Health Center Mijen
}

\author{
Tri Sakti Widyaningsih ${ }^{1 \text { (corresponding author) }}$, Yulianus Prabu $^{2}$, Menik Kustriyani $^{3}$ \\ ${ }^{1}$ Department of Nursing, STIKes Widya Husada Semarang, Indonesia; imoet.sakti@gmail.com \\ (koresponden) \\ ${ }^{2}$ Department of Nursing, STIKes Widya Husada Semarang, Indonesia; sakti_imoet@yahoo.com \\ ${ }^{2}$ Department of Nursing, STIKes Widya Husada Semarang, Indonesia; mtriyanie@ yahoo.co.id
}

Submitted: September 1, 2018 -Revised: October 11, 2018 -Accepted: October 17, 2018 -Published: October 31, 2018

\begin{abstract}
Background: Preliminary studies conducted by researchers on December 2015 at Public Health Center Mijen, Semarang get a yield of 7 people in the category of obesity, be found 2 people have a varicose veins in the legs and 5 other people not have varicose veins in the legs. Aim: Analyzing correlation between the level of obesity with events varicose vein on adult patients aged 26-45 years old in Public Health Center Mijen, Semarang. Methods: The research design was cross sectional. Samples were taken from adult obese patients who come to the Public Health Center Mijen Semarang as much as 42 respondents, selected by accidental sampling technique. Data were gathered using observation sheets, then analyzed using Spearman rank test. Results: The p-value of the Spearman rank test was 0.003 , with the correlation coefficient of 0.443 . Conclusion: There is a correlation between the level of obesity with the incidence of varicose veins on adult patients in Public Health Center Mijen Semarang. Suggestion: Recommended for respondent to control weight and attention intake foods consumed.
\end{abstract}

Keywords: Obesity; varicose vein, adult

\section{INTRODUCTION}

The nutritional problems in Indonesia are currently entering into multiple nutritional problems. That is, less nutritional problems are still not fully resolved, while already appearing more nutritional problems. Excessive nutrients that cause obesity can occur either in children up to adulthood. Obesity is caused by an imbalance between the amount of energy that enters and what the body needs for various biological functions such as physical growth, development, activity, health maintenance. ${ }^{(1)}$

Overweight or obesity is one of the risk factors for a person experiencing varicose veins. This is because the foot is too heavy to support the body causing blood circulation is inhibited and the emergence of varicose veins in the foot. ${ }^{(2)}$ Varicose veins are swollen veins with unusual shapes that generally appear on the feet. Varicose veins on the legs are experienced by one in five adults, and are especially more common in women. ${ }^{(3)}$

Varicose veins occur when one or more valves can not close. When this happens, the blood stops and stretches the veins, more far weakening the walls of blood vessels. With the weakening of the veins, more and more valves can not close properly. The veins become larger and wider as time goes on and starts to look like chunks Chains winding beneath the skin. ${ }^{(4)}$

Preliminary study conducted by researchers in December 2015 at Public Health Center Mijen, Semarang was obtained 7 people who are obese category there are 2 people who have varicose veins on his legs and 5 others there are no varicose veins on his legs, from 2 respondents who have varicose veins get IMT value for first responders 31.11 .

\section{METHODS}

This study was an analytic survey research with cross sectional design, that was research type that emphasizes time of observation measurement of independent variable and dependent variable only once at one time point approach. ${ }^{(5)}$ This study was conducted in March 2016 for 1 week, the sample size in this study was 42 people, selected using accidental sampling. The inclusion criteria were adult patients (26-45 years old) who were obese, willing to be respondents. Exclusion criteria of families with a history of varicose veins (heredity), pregnant women, workers who need standing or sitting long. Data were collected using observation sheet for obese and varicose veins. The obesity observation sheet was not tested for validity because it was standardized using the Body Mass Index, whereas the varicose veins observation sheet had been tested by Expert Lecturer of 
Universitas Diponegoro, Wahyu Hidayati, S.Kp, M.Kep, Sp.KMB. Data were analyzed by using Spearman rank test.

\section{RESULTS}

Table 1. The Correlation Between The Level of Obesity With The Incidence of Varicose Vein on Adult Patients in Public Health Center Mijen, Semarang

\begin{tabular}{|c|c|c|c|c|c|c|}
\hline \multirow{2}{*}{ Level of obesity } & \multicolumn{5}{|c|}{ The incidence of varicose vein } \\
\cline { 2 - 7 } & \multicolumn{2}{|c|}{ No varicose } & \multicolumn{2}{c|}{ Risk varicose } & \multicolumn{2}{c|}{ Be found varicose } \\
\cline { 2 - 7 } & Frequency & Percentage & Frequency & Percentage & Frequency & Percentage \\
\hline $\begin{array}{c}\text { Obesity I } \\
(\text { IMT = 25-29.9) }\end{array}$ & 11 & 52.38 & 0 & 0 & 10 & 47.62 \\
\hline $\begin{array}{c}\text { Obesity II } \\
(\text { IMT = >30) }\end{array}$ & 0 & 0 & 4 & 19.05 & 17 & 80.95 \\
\hline & \multicolumn{2}{|c|}{ p-value $=0.003$} & $\rho=0.443$ & & & \\
\hline
\end{tabular}

Based on table 1 it can be clearly understood that the proportion of varicose incidence was more common in the obesity II group which was 80 percent. The Spearman correlation test results showed a p-value of 0,000 so that it was interpreted that obesity levels correlated with the incidence of varicose veins.

\section{DISCUSSION}

Based on the results of this study, it was interpreted that obesity levels correlated with the incidence of varicose veins on adult patient at Public Health Center Mijen, Semarang. Most of the respondents in health center area were between 36-45 years old from total 42 respondents. Obesity that occurred at the Public Health Center Mijen, Semarang more existed at the age of 36-45 years of which 28 people from a total of 42 respondents. The incidence of varicose veins in the Public Health Center Mijen, Semarang was mostly experienced by the 36-45 age group. Most of the respondents in area of Public Health Center Mijen, Semarang were female.

Obesity occurring in the area of Public Health Center Mijen, Semarang were obesity I (BMI of 25-29.9) and obesity II (BMI of > 30), which means incidence of obesity I and obesity II in Public Health Center Mijen, Semarang is balanced from a total of 42 respondents. The most of respondents had the varicose veins (27 from a total of 42 respondents). This happens because of nutrient intake and unbalanced vitamins (the type and quantity of food that does not fit the needs of the body) causes obesity and cause varicose veins in respondents, it is revealed by the respondents that the respondents eat as usual without seeing the intake in the consumption is sufficient for the body or excessive for So that it causes obesity and cause varicose veins.

While 4 people who are at risk for varicose veins from a total of 42 respondents according to the researchers, this happens because obese people still do sports activities although very rarely done, it is revealed by respondents that respondents are still exercising but rarely, it makes blood supply or blood circulation is still well, although the respondent complained about the pain in the legs, cramps, itching around the blood vessels, the legs felt heavy, the legs had a twitching sensation, but not yet the color changes in blood vessels, spider vein, or venous stiffness, so it is still at risk of varicose veins. While 11 people who did not occur varicose from the total of 42 respondents according to the researcher, this in because obesitas happened to new respondent few month happened, this matter expressed by the respondents that weight of new responden rise a few month ago, so it has not caused blood vessels weakened and there has been no widening in the blood vessels so that has not happened varicose veins. As for the symptoms encountered in the respondents during the research conducted at the Public Health Center Mijen, Semarang such as the feeling of pain in the legs, cramps in the legs, itching around the blood vessels, legs feel heavy, discoloration of the skin (skin color to purple bluish), blood vessels which resemble spider veins, and venous stiffness.

One solution for the respondents at the Public Health Center Mijen, Semarang who have not experienced varicose veins is by providing knowledge to respondents about prevention of incidence of varicose veins is by controlling weight, add fiber in food consumption, avoid heavy impact aerobics, put the position of the foot higher during sleep, wear comfortable shoes, do not stand and sit still too long, do not wear tight clothes, avoid spicy, salty, and fatty foods, consumption of vitamin C. The solution for the respondent in Public Health Center Mijen, Semarang which already has varicose veins in his legs is to recommend the respondent to do the treatment in accordance with the doctor's recommendation that the consumption of omega-3 fatty acids as much 
as $100 \mathrm{mg} /$ day, ginkgo biloba consumption as much as $120 \mathrm{mg} /$ use stocking compression or stocking special varicose. Stocking used for the treatment of varicose veins serves to suppress the blood vessels so that the volume of blood vessels is not restrained in the veins. ${ }^{(6)}$ If it has passed several treatments and therapies, but varicose veins do not heal as well, there are some special treatments that can be applied such as through the path of laser surgery, endoscopic vein surgery. ${ }^{(7)}$

\section{CONCLUSION}

Based on the results of this study, it was concluded that obesity levels correlated with the incidence of varicose veins on adult patient at Public Health Center Mijen, Semarang.

\section{REFERENCES}

1. Sudargo T, et al. Diet and Obesity (Pola Makan dan Obesitas). Yogyakarta: Gadjah Mada University Press; 2014.

2. Proverawati A. Obesity and Eating Disorders in Adolescents (Obesitas dan Gangguan Perilaku Makan pada Remaja). Yogyakarta: Nuha Medika; 2010.

3. Suhartono. Bad Impact of Varicose Veins (Dampak Buruk Varises) [Internet]. 2013 [cited 2015 Dec 18]. Available from: http://wordpres.com

4. Arkoso TH. Free from varicose veins (Bebas Varises). Yogyakarta: Kanisius; 2009.

5. Notoatmodjo S. Health Research Methodology (Metodologi Penelitian Kesehatan). Jakarta: Rineka Cipta; 2012.

6. Dinkes Prov. Sumbar. Types of varicose veins and how to overcome them (Macam-macam varises dan cara mengatasinya [Internet]. Dinkes Prov Sumbar. 2013 [cited 2016 Jan 7]. Available from: http://dinkes.sumbarprov.go.id

7. Varises.org. Varicose veins and their ailments (Varises dan Penyakitnya) [Internet]. Varises.org. 2011 [cited 2015 Dec 15]. Available from: http://varises.org 